\title{
The construction of the Porto School
}

\author{
E. Fernandes
}

EAUM, LAB2PT, Guimarães, Portugal

\begin{abstract}
The expression 'School of Porto' implies an idea of Portuguese Architecture that began in the mid-fifties, in the work of Fernando Távora. In this text, we present an analysis of the Tennis Pavilion of Quinta da Conceição (1957) as an example of Távora's tectonic shift of the 50s, inspired by the simultaneous influence of Portuguese vernacular construction and of the international debate. This work, along with the others which Távora designed in these years, marks the beginning of a new identity in Portuguese architecture.
\end{abstract}

\section{INTRODUCTION}

As a consequence of the international impact of the work of Portuguese architects Álvaro Siza Vieira (Pritzker winner in 1992) and Eduardo Souto Moura (Pritzker winner in 2011), the socalled Porto School has become a global phenomenon. But the expression 'School of Porto' implies an identity that began in the mid-fifties, in the work of Fernando Távora.

The six years (1955-61) that mediated between the beginning of the work process of the Surveys on Portuguese Vernacular Architecture and the publication of the book Popular Architecture in Portugal (which summarizes its conclusions) were a period of great importance in the work of Távora, in which the first notable works of the School of Porto were built.

In order to understand the important evolution of his work at this time, it is essential to remember that Távora was present at the main international architectural meetings promoted in the 1950s, where he had the opportunity to contact with the key names of the worldwide architectural community: he participated in the International Congress of Artists promoted by Unesco in Venice (1952), he integrated the Portuguese representations present in the last CIAM Congresses and also participated in the Team Ten meeting of Royaumont (1962).

It is obvious that the participation in these international meetings, along with his important role in the abovementioned Surveys, allowed important evolutions in Távora's architecture; it can hardly be considered a coincidence that, in the mid-50s, it is finally possible to recognize in his constructed work the principles previously enunciated in his texts. This shift was materialized by the appearance of tectonic features which allowed his architecture to be both modern and Portuguese. 


\section{THE TECTONICS OF THE WORK OF TÁVORA IN THE MID-FIFTIES, BETWEEN VERNACULAR ARCHITECTURE AND THE INTERNATIONAL DEBATE}

\subsection{Premises}

On the 10th of November of 1945, when Fernando Távora was a 22-year-old student of the Fine Arts School of Porto, he published a text called "The Problem of the Portuguese House" (Távora, 1945). This was a very courageous text, published under the dictatorship of António Salazar, criticizing the official architectural doctrine of the fascist regime at a time when the state censorship was very strong (Fernandes, 2016). This moment marks the beginning of a theoretical construct that Távora accomplishes in the next ten years, in the defense of an architecture that was, simultaneously, Portuguese and Modern, while many of his colleagues advocated an uncompromising internationalism, a position that was strongly manifest at the 1948 Congress of the Portuguese Architects (Bandeirinha, 1996).

However, between the mid-40s and the mid-50s, Távora's texts presented a set of ideas that he could not materialize in his buildings. Thus, the signs of the genesis of a new Portuguese Architecture only began to appear in the work of Távora after 1955: in the Municipal Market of Vila da Feira (1954-59), in the Ofír House (1957-58), in the Tennis Pavilion of Quinta da Conceição (1956-59) and in the Cedro Elementary School (1957-61). As Nuno Portas accurately states (referring to the Tennis Pavilion) these are buildings "where the domain of scale is so secure it relies on the very nature of materials", where Távora "realistically adopts traditional materials and techniques, subjected to a conversion of modernity in the concept of volumes, planes, light-dark contrast and vigour" (Portas, 1961: 22). In all the above mentioned works, developed in a short period of time, we can recognize the full realization of the intentions expressed in his theoretical work: its modernity is expressed in the "quality and accuracy of its relationships with life", in a "seamless integration of all its elements" (Távora, 1952).

For Távora, 'modernity' was a timeless value, implying an adaptation to the conditions of the present time, combining the specificity of each site and context with the influence of coeval foreign architecture. Thus, the methodological approach which characterizes his activity in the second half of the 50s can be synthetized in terms of effectiveness, empiricism, consistency and efficiency; in other words, by a blend of common sense and rationality.

Therefore, the abovementioned works represent an epistemological construct that was finally materialized in a tectonic shift, which occurred simultaneously with the work process of the abovementioned Surveys, where Távora could recognize the presence of modernity in vernacular architecture.

\subsection{The importance of the Survey}

In the abovementioned 1945 text, Távora claimed that the study of Portuguese vernacular architecture was still undone, stating that this study was vital and should be an "element of the new architecture". He argued that Portuguese architects should study the relationship of traditional constructions with the conditions that had created them, whether they were "conditions related with the Man", or "conditions related with the Land". Claiming that "the vernacular house will give us great lessons because it is truer, more functional and less fanciful" (Távora, 1945, p. 10), he stated the necessity of conducting these studies ten years prior to the beginning of the field work of the abovementioned Surveys on Portuguese Vernacular Architecture, a large program promoted by the Union of the Portuguese Architects and conducted by some of the most renowned architects from Porto and Lisbon: Fernando Távora, Lixa Filgueiras, Keil do Amaral, Nuno Teotónio Pereira, Frederico George e Artur Pires Martins. 
These Surveys recorded information that constituted a precious memory about a disappearing reality; but the field work involved was also a catalytic element to the reinterpretation of the traditional tectonic systems of Portuguese vernacular constructions in the light of the modern principles of rationality, functionalism and truthful use of materials. The book Popular Architecture in Portugal (published in 1961) was the direct result of the research carried out between 1955 and 1960. The published synthesis presented the result of a joint effort, coordinated by Keil do Amaral and following general principles established for the six groups; however, we can consider Távora the author of the contents of the "Zone 1" report (covering the geographic areas of Minho, Douro Litoral and Beira Litoral), as he was the coordinator of the team, which also included Rui Pimentel and António Menéres, two young architecture students at the time.

In this report there is a clear intention of analysing the geography and the history of the sites, while paying special attention to the human component: the uses that are found in each region are justified by the hydrographic characteristics, the relief, the climate, the constitution of the soils and the history of the settlement and, in turn, justify the types of occupation of the territory and the forms and techniques of construction. Likewise, the local conditions and way of life of the population explain the relation with the site, the tectonic options of the buildings and the internal organization of the housing.

The fascination that the harmony of these rural settlements present to the authors is evident, both in the texts and in the images. Besides, the analysis emphasizes that the compositional scheme does not depend on the size of the settlement: in the houses of the richest farmers, the dimension increases but animals and people are still lodged side by side. The use is predominant; if it does not change, the typology remains the same, although the scale is different.

The report of "Zone 1" confirms what Távora had already affirmed fifteen years earlier: "Man and Earth" are the two fundamental elements that condition vernacular architecture, which is realized "within the Portuguese truth"; thus, the ancient rural house is "the truest, most functional and less fanciful" (Távora, 1945). So, this Survey is the point of arrival of a long process of maturation, considering vernacular tectonics as a conceptual model, instead of seeing it as a mere source of formal guidelines: its lessons can be reinterpreted in new types of implementation, in different functional schemes and with innovative constructive processes. This reinterpretation led to a very clear tectonic shift in Távora's work; the tennis pavilion of Quinta da Conceição, which will be object of analysis in this text, is one of the most evident results of this learning process.

\subsection{The Tennis Pavilion of Quinta da Conceição: tectonic analysis}

The Tennis Pavilion is part of Távora's intervention in Quinta da Conceição, the reuse of the grounds of an old convent (of which subsisted very few traces) for a public recreational park.

The introduction of the flat surface of the tennis court on the sloping ground of the park implied some earthmoving; Távora located the new building on the north side of the tennis court, taking advantage of the terrace created by the new land support wall.

The pavilion has two levels: on the upper floor there is an open shelter for the spectators of tennis matches; on the ground floor, there are bathhouses and bathrooms for the players and a storage compartment. The facilities of the lower floor are located in a semi-buried box, hidden behind the surface of the stone support wall, two meters high, which is only interrupted by the three wooden doors. Above this wall there is a concrete lintel, half a meter high, which is based on the stone below; its length exceeds half a meter the size of the façade of the bathhouses, overlapping the land support wall on both sides.

On this lintel rests the upper floor slab, extended 1.6 meters past the alignment of the lower floor façade. Sideways, the slab is viewed as a horizontal plane, highlighted by the cantilever.

On the contrary, in a frontal view, the horizontal plane is hidden by a concrete beam in balance (connected to the floor slab), forming a rectangular plane (1.2 meters high and 12.9 meters long) 
which seems to float in front of the stone wall. Inside the shelter, on the upper floor, it acts as a safety protection; but it also extends downwards, 0.5 meters, hiding the aforementioned concrete lintel from the front view. On both sides, the concrete is left in view, with its rough appearance.

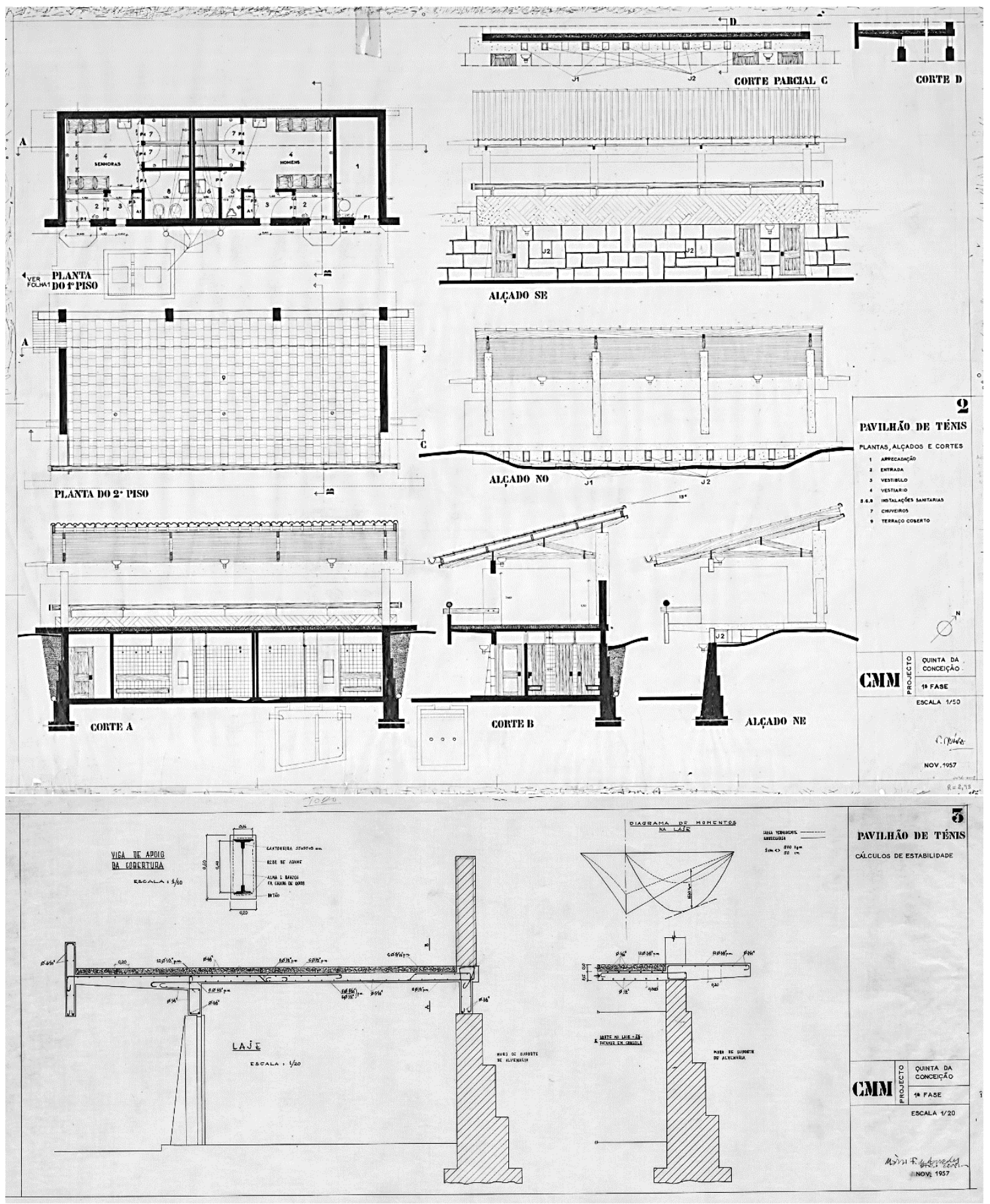

Figure 1. Original drawings of the Tennis Pavilion of Quinta da Conceição. Fernando Távora, 1957. Fernando Távora archives, Marques da Silva Foundation (FIMS/FT/0036-pd007; FIMS/FT/0036-pd008).

Above this floating rectangular plane stands another element, a 13.5 meter long wooden cylinder (with a diameter of 0.2 meters) made with a single piece of wood and secured by seven delicate 
iron supports, so thin they are unnoticeable from a few meters away. From inside the shelter, this element acts as a handrail; however, on both sides, it extends ( 0.7 meters) beyond the necessary for its function, accentuating the neoplastic character of the composition.

On the upper floor, on both sides of the pavilion, we find two stone plastered walls ( 2 meters high and 3.4 meters long) based in the horizontal slab. These elements present themselves as the dominant elements of the lateral façades, shaping the space inside the shelter, but they do not enclose it completely. On the back side, there is a 1.1 meter passageway that allows access to the interior, while on the front side there is a 1.2 meter empty space above the abovementioned cantilever. In this empty space (on both sides of the pavilion) appears a wooden board $(0.2 \times 1.25$ meters) protecting the users from falling. It is attached to the wall, on one side, and the other end fits between the handrail and the concrete protection of the main façade; in both directions, it extends beyond the necessary dimension for its function and fixation.
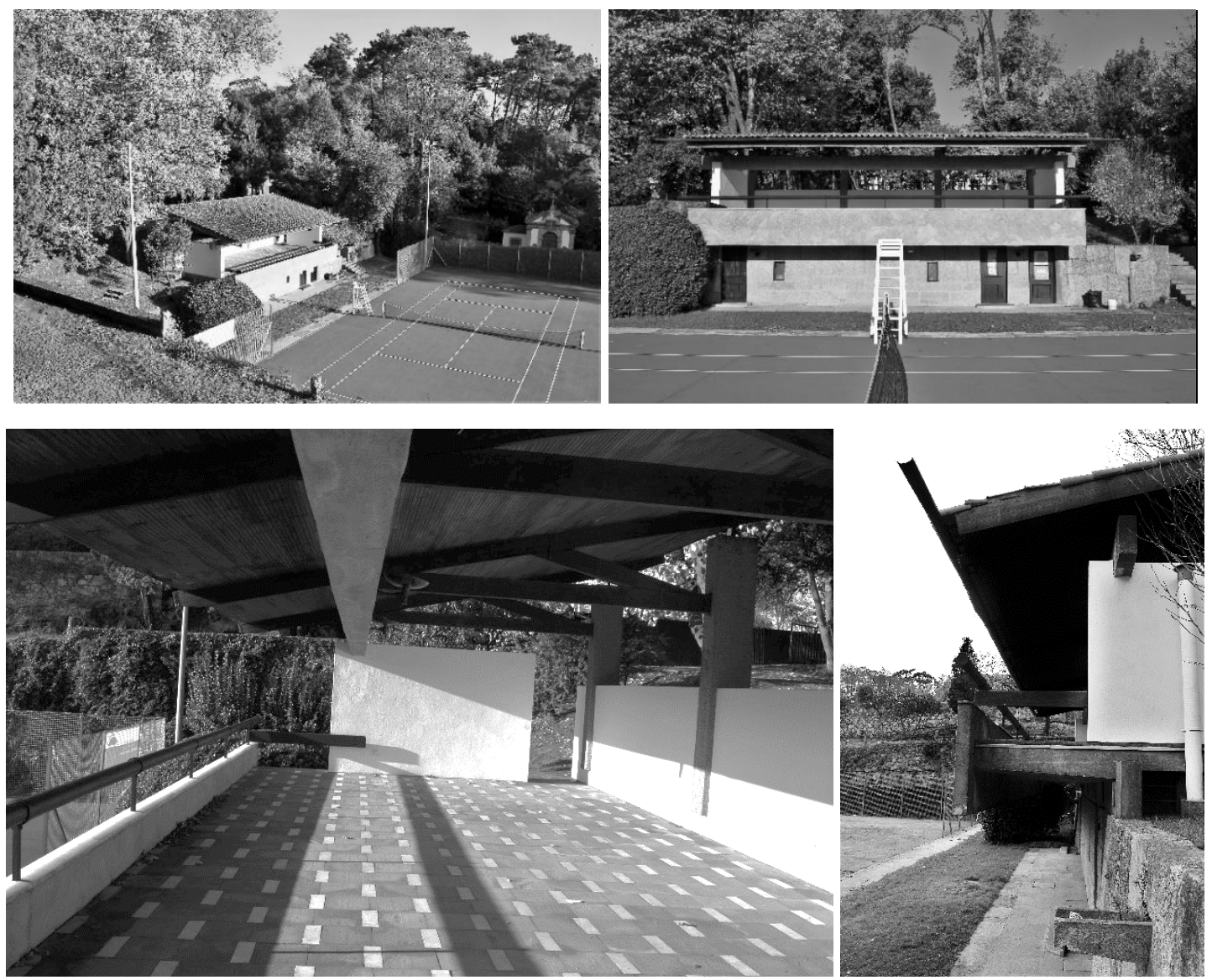

Figure 2. Tennis Pavilion of Quinta da Conceição. Fernando Távora, 1957.

Photos of the current state by Eduardo Fernandes (2018).

Enclosing the space at the back, there is a third stone plastered wall (1.7 for 14.4 meters); the empty space left between this wall and the roof (inclined forward) allows the players in the tennis court to see the landscape behind the pavilion. It is sectioned by four embedded stone pillars $(0.3$ for 0.5 section, 3.25 meters high) which do not touch the ground (stopping at 0.3 meters).

These pillars hold the four elements of the timber structure, designed asymmetrically, which support the sloped roof covered with tiles. At the front, these structural elements are supported by a concrete beam, which appears in the same plane of the concrete lintel of the ground floor, and 
has the same size ( 0.5 meters high and 13.8 meters long). This beam rests on the two plastered walls of the lateral façades, in a daring asymmetrical structural composition. The way these elements engage is reminiscent of the traditional wooden construction systems: the wall is trimmed to allow the half-height engagement of the beam, which exceeds 0.5 meters the necessary length, on both sides.

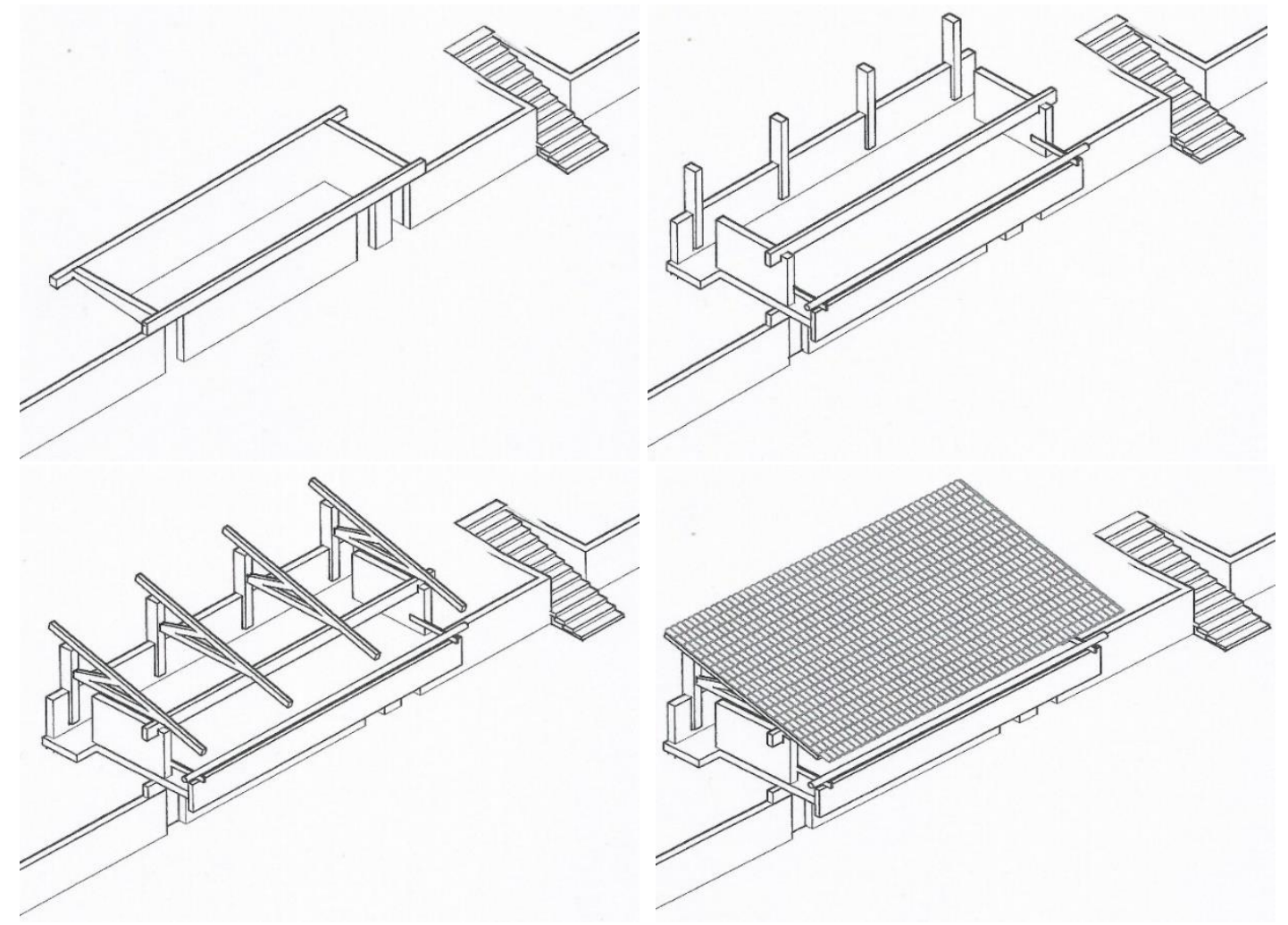

Figure 3. Juxtaposed elements of construction in the Tennis Pavilion of Quinta da Conceição. Drawings by Eduardo Fernandes.

This is one of the favourite works of the author, because it happens at a time "of great conviction and professional hope"; although, it "is of no use" from a strictly functional point of view, as the author himself admits, adding that this is "the highest compliment that can be made" (Távora, 1993a: 74). In fact, if the facilities in the ground floor have an obvious function, the shelter on the top is not very useful, as the friendly matches taking place in this court do not imply a large audience; but even if they did, the visibility for the tennis court is not good for those who are not in the front line of the shelter.

However, the pavilion has another function, a pedagogical role, very important at this particular moment of Portuguese architecture. Located in a leisure area accessible to the public, just a few kilometres from Porto, the Tennis Pavilion presented a perfect location: it was closer and more accessible for the architecture students of the School of Fine-Arts of Porto (where Távora taught since 1951) than the other works that Távora constructed at the same time. We believe this is why Távora was so obviously concerned with the "quality of manual labour" in the written specifications of the project: he claimed that "this is a building with very special characteristics, where one cannot forgive the slightest fault", emphasizing the necessity of "the best quality in the concrete formwork" and of a "careful finishing of the carpentry" (Távora, 1957: 1-6). 
The discourse that Távora elaborated for the holiday house he designed in Ofír (a summer resort forty kilometres to the north), also in 1957, can also characterize the Tennis pavilion: "One of the most elementary notions of chemistry teaches us the difference between a compound and a mixture; such a notion seems to us to be perfectly applicable, in essence, to the particular case of a building. In fact there are buildings that are compounds and buildings that are mixtures (...) and in the present case of this dwelling (...) we tried to build a true compound, a compound in which an infinite number of factors, of varying value, came into play" (Távora, 1993b: 78).

In both these works Távora seeks to build a compound of many factors. But in the house of Ofir, the work was conditioned by the obedience to a program and by the needs of a client. On the contrary, in the tennis pavilion, the architect is free to materialize his ideas, making it obvious that he understands "the meaning of organicism, functionalism, neo-empiricism, cubism" and "feels a love without limits for all the manifestations of the spontaneous architecture of his country” (Távora, 1993b: 80).

\subsection{The Tennis Pavilion: foreign parallels and references}

In Hoddesdon, Aix-en-Provence and Dubrovnik, Távora witnessed the confrontation between the future Team Ten members and the older (and more orthodox) members of CIAM. In some architects of the new generation, he recognized a theoretical position that was close to his ideas, which were expressed in his own writings since 1945, but only had a clear practical consequence in his work after the mid 50s. Thus, in these CIAM meetings he could confirm the pertinence of the 'third way' he defended, as an alternative to nationalism and internationalism, based on three principles: learning from the past, thinking about the present and projecting the future.

For instance, it is recognizable in the Tennis pavilion the will to express the memory of the wood construction in the design of concrete elements, mainly in the connection between the concrete lintel and the walls of the first floor. This theme can also be found in the Japanese architecture of the time, namely in the work of Kenzo Tange.

Távora met Tange in 1951, in Hoddesdon, where he was a member of the Japanese delegation. The paths of the two architects were to cross again in 1959 at Otterlo's meeting of Team X; apparently, they shared the same principles and became friends, as Távora refers when he remembers (in his diary) their reunion in Tokyo in the World Design Conference of 1960 (Távora, 2012: 305). Thus, the resemblances between the tennis pavilion and the house Tange built for himself in Tokio, in 1953, are not surprising; both the works are a compound between modern and traditional architecture.

But there is a less obvious parallel that we can establish. For Távora, the commission of this work was an equivalent circumstance to the one presented to Mies van der Rohe in the Barcelona's pavilion (1927): an opportunity, free of restraints, to realize his architectural ideas at a key moment of his career, after an important process of discovery and consolidation of his language. So, in both cases, the result is a manifesto, a demonstration of a (new) way of doing.

In Barcelona, Mies achieves a "suprematist-elementarist composition" of modern materials (Frampton, 1985: 197) where each one of its parts (steel pillars, cover slab, marble or glass walls) coexists with the others as an individual element; together, they imply directions for the movement of the visitors without enclosing the space.

In Leça da Palmeira, Távora revisits these principles but applies them to traditional building materials, with constructive techniques inspired by vernacular constructions, with wedge fittings of juxtaposed elements. Although the interior space is less dynamic, the exterior image presents a play of planes and lines reminiscent of the neoplastic experiences of the Dutch architects of the De Stijl movement (notably Gerrit Rietveld's Schroder-Schrader house), which were also very important in the shift of Mies architecture, in the mid 20s. However, in the tennis pavilion, the 
modern character of the composition is perfectly compatible with the presence of a Portuguese character, rooted in the vernacular tradition.

\section{CONCLUSION}

During the years of the Survey, Távora managed to combine in his work a particular understanding of the modern movement and an unconditional love for Portughese vernacular construction. It was in this compound of foreign influences and local character that the architecture of the Porto School was born, in this fusion between architectural avant-garde and traditional heritage, taking place in Vila da Feira, Gaia, Ofir and Leça da Palmeira, almost at the same time.

In the Tennis pavilion of Quinta da Conceição, we discover that popular architecture is truly functionalist (and can even be neoplastic), and that this character is not necessarily incompatible with an organicist and empiricist attitude. We find a building that relates "to everything that surrounds it, even if it is not apparent or evident", an architecture that "inhabits a world of simplicity and magic" (Siza, 1993: 69). We feel the existence of an "unnamed quality" which is synonymous of life in a building or a space, product of a "timeless way of building" (Alexander, 1979). This is the quality Raul Lino calls "Character", which transforms the work "from an inert object, in one that vibrates, arouses interest and attracts" (Lino, 1933: 48); it can also be called "Atmosphere" (Zumthor, 2006) and be described as a mathematical creation of the mind which, using inert materials and starting from utilitarian conditions, establish relations that excite emotion (Corbusier, 1923: 145).

These features configure a new identity: when Távora stated "I am the Portuguese Architecture" (Moura, 1993: 71), this was more than an irony, typical of the peculiar sense of humour that characterized him; it meant the desire to affirm a new identity in Portuguese architecture, presented in his own work.

\section{REFERENCES}

Alexander, C. 1979. The Timeless way of Building. New York: Oxford University Press.

Bandeirinha, J. A. 1996. Quinas Vivas. Porto: FAUP.

Corbusier. 1923. Vers une Architecture. Paris: Ed. Crés.

Fernandes, E. 2016. Os CODA da EBAP nos anos 40. In Fátima Ferreira, Francisco Mendes, Natália Pereira (ed.), A Conquista Social do Território: 39-56. Coimbra: Tenacitas.

Frampton, K. 1985. Modern architecture: a critical history. London: Thames and Hudson.

Lino, R. 1933. Casas portuguesas - Alguns apontamentos sobre o arquitectar das casas simples. Lisboa: Ed. Valentim de Carvalho.

Moura, E. S. 1993. A «Arte de Ser Português». In Luiz Trigueiros (ed.), Fernando Távora: 71-72. Lisboa: BLAU.

Portas, N. 1961. Fernando Távora: 12 anos de Actividade Profissional. Arquitectura 71: 11-34.

Siza, Á. 1993. A propósito da Arquitectura de Fernando Távora. In Luiz Trigueiros (ed.), Fernando Távora: 69. Lisboa: BLAU.

Távora, F. 1945. O Problema da Casa Portuguesa. ALÈO 5(IV): 10.

Távora, F. 1952. Arquitectura e Urbanismo - a lição das constantes. Lusíada 2(1): 151-155.

Távora, F. 1957. Projecto do Pavilhão de Ténis, Quinta da Conceição, Peças Escritas, Caderno de Encargos. Espólio Fernando Távora (pasta 36), Fundação Marques da Silva.

Távora, F. 1993a. Pavilhão de Ténis, Quinta da Conceição, 1956-1960. In Luiz Trigueiros (ed.), Fernando Távora: 74. Lisboa: BLAU.

Távora, F. 1993b. Casa de Ofír, 1957-1958. In Luiz Trigueiros (ed.), Fernando Távora: 78. Lisboa: BLAU. Távora, F. 2012. Diário de 'Bordo' (fac-simile). Guimarães: Guimarães 2012, FMS, CA, FFT.

Zumthor, P. 2006. Atmosferas. Barcelona: Gustavo Gili. 